\title{
The Monitoring of $\mathrm{H}_{2} \mathrm{~S}$ and $\mathrm{SO}_{2}$ Noxious Gases from Industrial Environment with Sensors Based on Flame-spray-made $\mathrm{SnO}_{2}$ Nanoparticles
}

\author{
Chaikarn Liewhiran $^{1,4, *}$, Nittaya Tamaekong ${ }^{2}$, Anurat Wisitsora-at ${ }^{3}$, \\ and Sukon Phanichphant ${ }^{4}$ \\ 1 Department of Physics and Materials Science, Faculty of Science, Chiang Mai University, Chiang Mai \\ 50200, Thailand \\ 2 Program in Materials Science, Faculty of Science, Maejo University, Chiang Mai 50290, Thailand \\ 3 Nanoelectronics and MEMS Laboratory, National Electronics and Computer Technology Center, Klong \\ Luang, Pathumthani 12120, Thailand \\ 4 Materials Science Research Center, Faculty of Science, Chiang Mai University, Chiang Mai 50202, \\ Thailand \\ E-mail: chaikarn_1@yahoo.com*
}

\begin{abstract}
The noxious gas sensors were developed successfully using flame-spray-made $\mathrm{SnO}_{2}$ nanoparticles as the sensing materials. The functionalized nanoparticle properties were further analyzed by XRD, BET and TEM analyses. The $\mathrm{SnO}_{2}$ nanoparticles (SSABET: $141.6 \mathrm{~m}^{2} / \mathrm{g}$ ) were investigated revealing non-agglomerated spherical, hexagonal, rectangle (3-10 nm), and rod-like (3-5 $\mathrm{nm}$ in width and 5-20 $\mathrm{nm}$ in length) morphologies. The sensing films were prepared by spin coating onto the $\mathrm{Al}_{2} \mathrm{O}_{3}$ substrates interdigitated with $\mathrm{Au}$ electrodes. The sensing films were significantly developed in order to detect with $\mathrm{H}_{2} \mathrm{~S}$ $(0.5-10 \mathrm{ppm})$ and $\mathrm{SO}_{2}(20-500 \mathrm{ppm})$ at the operating temperature ranging from 200$350^{\circ} \mathrm{C}$. After sensing test, the cross-section of sensing film was analyzed by SEM analyses. It was found that $\mathrm{SnO}_{2}$ sensing film showed higher sensitivity to $\mathrm{H}_{2} \mathrm{~S}$ gas with very fast response at lower concentrations ( $3 \mathrm{~s}$, to $10 \mathrm{ppm}$ ). The cross sensitivities of the sensor towards different concentrations of $\mathrm{H}_{2} \mathrm{~S}, \mathrm{CO}, \mathrm{H}_{2}$, and $\mathrm{C}_{2} \mathrm{H}_{2}$ were measured at $300^{\circ} \mathrm{C}$. The sensor evidently shows much less response to $\mathrm{CO}, \mathrm{H}_{2}$, and $\mathrm{C}_{2} \mathrm{H}_{2}$ than to $\mathrm{H}_{2} \mathrm{~S}$ indicating higher selectivity for $\mathrm{H}_{2} \mathrm{~S}$ of the $\mathrm{SnO}_{2}$ sensor at the lower concentration (10 ppm). Therefore, the $\mathrm{SnO}_{2}$ sensor was the most suitable candidate for the efficient detection of $\mathrm{H}_{2} \mathrm{~S}$ noxious gas.
\end{abstract}

Keywords: $\mathrm{H}_{2} \mathrm{~S}, \mathrm{SO}_{2}$, noxious gas, environmental sensors, $\mathrm{SnO}_{2}$, flame spray pyrolysis.

ENGINEERING JOURNAL Volume 16 Issue 3

Received 18 November 2011

Accepted 6 February 2012

Published 1 July 2012

Online at http://www.engj.org/

DOI:10.4186/ej.2012.16.3.123

This paper is based on the oral presentation at the German-Thai Symposium on Nanoscience and Nanotechnology 2011_Green Nanotechnology of the Future, GTSNN 2011, in Nakbon Ratchasima, Thailand, 13-16 September 2011. 


\section{Introduction}

Hydrogen sulfide $\left(\mathrm{H}_{2} \mathrm{~S}\right)$ is a toxic gas produced from the coal, oil, and natural gas industries [1-7]. The high toxicity of $\mathrm{H}_{2} \mathrm{~S}$, which has significant negative impacts on health and the environment, has attracted attention to monitor and control this gas. With a maximum allowed limit in the atmosphere of $10 \mathrm{ppm}_{2} \mathrm{~S}$ [6], developing reliable sensors with high sensitivity and also selectivity towards other gases is a real challenge. Sulfur dioxide $\left(\mathrm{SO}_{2}\right)$ gas is one of the most toxic and common air pollutants $[4,8,9]$. Due to growing concern on environmental issues, much attention has been focused on the monitoring of air pollutants. $\mathrm{SO}_{2}$ is one of the major gases that cause a serious air pollution problem. The most important application falls in the category where human beings cannot afford to risk smelling noxious gases. Also, an exposure to $\mathrm{SO}_{2}$ can cause irritation to eyes, skin and respiratory system. These are the reason for increasing requirements to monitor the gas pollutions in urban agglomerates or in the work ambient atmosphere $[8,9]$. The long-term exposure limit and the short-term exposure limit of sulfur dioxide gas are 2-5 ppm, respectively, although the acceptable limit of $\mathrm{SO}_{2}$ in ambient air is much less. Nevertheless, the monitoring of $\mathrm{SO}_{2}$ leakage at the source may be helpful to contain not only the accidental exposure at the source but also environmental pollution in general $[8,9]$. Therefore, rapid detections of poisonous and hazardous gases including $\mathrm{H}_{2} \mathrm{~S}$ and $\mathrm{SO}_{2}$ in technological wastes are challenging.

Recently, metal oxide semiconductors (MOS) [10-17] have been extensively investigated for this purpose due to their simplicity, small dimensions and attractive price. Several types of metal oxide semiconductors have been used as sensing material for different type of gases. $\mathrm{SnO}_{2}$ is one of the most promising materials for sensor and has attractively established the attention of many users and scientists' interest in gas sensing under atmospheric conditions. It is a wide band gap and the best-understood prototype of oxide-based gas sensors for the detection of various noxious gases especially $\mathrm{H}_{2} \mathrm{~S}$ and $\mathrm{SO}_{2}[1-$ 9]. In the present study, Flame Spray Pyrolysis (FSP) is presented as a very promising technique for sensor material fabrication since it enables primary particle and crystal size control $[18,19]$, which is important to improve the sensitivity, as well as controlling in situ deposition of noble metal clusters [19]. It has been shown that due to the morphology of the FSP-made particles, the mass transfer rates in catalysis are higher compared to microporous material because of the large external surface area of flame-made materials [19, 20]. Moreover, the importance of the size control, the required large and easily accessible surface area (large pore size, no micropores), the efficiency of noble metal doping, and competitive production rates put high demands on the method of nanoparticles production for sensor materials. Therefore, it is interesting to apply FSP for production of $\mathrm{SnO}_{2}$ nanoparticles to be used in environmental gas sensors. In this work, the applicability of FSP in synthesis of $\mathrm{SnO}_{2}$ nanoparticles for noxious gas sensing from industrial environment is reported. The aim is to demonstrate that the FSP process in general can be successfully applied for sensor material production and to specifically evaluate the noxious i.e. $\mathrm{H}_{2} \mathrm{~S}$ and $\mathrm{SO}_{2}$ performance of environmental gas sensors.

\section{Experimental}

\subsection{Flame Synthesis}

Figure 1 shows the set up for FSP process used to produce the flame-spray-made $\mathrm{SnO}_{2}$ nanopowders. Precursor solutions $(0.50 \mathrm{M})$ were prepared by dissolving appropriate amounts of tin (II) 2-ethylhexanoate (Aldrich, 95\%) used as Sn in xylene (Carlo Erba, 98.5\%). The precursor mixture was fed into a nozzle at a constant feed rate of $5 \mathrm{ml} / \mathrm{min}$ using a syringe pump. At the end of the nozzle the precursor solution was dispersed by $4.30 \mathrm{l} / \mathrm{min}$ oxygen forming a spray with a pressure drop at the capillary tip kept constant at 1.5 bars by adjusting the orifice gap area. A sheath gas flow of $3.92 \mathrm{l} / \mathrm{min}$ of $\mathrm{O}_{2}$ was supplied concentrically around the nozzle to stabilize and control the spray flame. The spray was ignited by supporting flamelets fed with oxygen $(2.46 \mathrm{l} / \mathrm{min})$ and methane $(1.19 \mathrm{l} / \mathrm{min})$, which were positioned in a ring around the nozzle outlet. The observed flame height was approximately $10 \mathrm{~cm}$ and appearance was light orange. The combustion enthalpies were directly dependent on the particular solvent, starting materials. After evaporation and combustion of precursor droplets, particles were formed by nucleation, condensation, coagulation, and coalescence. Finally, the nanopowders were collected on a glass microfibre filters (Whatmann GF/A, $25.7 \mathrm{~cm}$ in diameter) with the aid of a vacuum pump (Busch, Seco SV 1040C). 


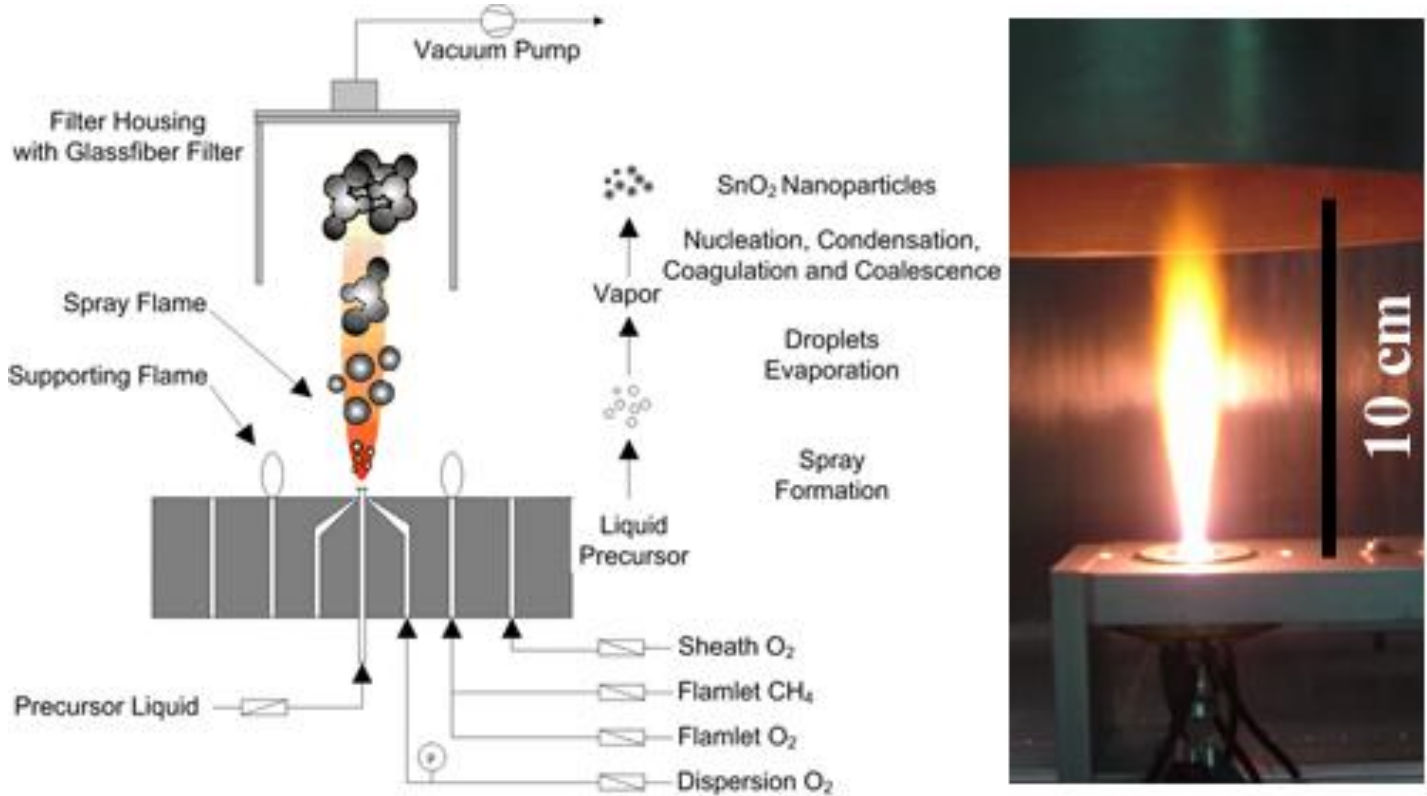

Fig. 1. Schematic diagram of FSP process and flame appearance.

\subsection{Nanopowder Characterizations}

The nanopowders phase was analyzed by X-ray diffraction (XRD) [Phillips X-'pert] using CuK $\alpha$ radiation $(20 \mathrm{kV}, 20 \mathrm{~mA})$ with a scanning speed of $5^{\circ} / \mathrm{min}$. The Brunauer-Emmett-Teller (BET) specific surface area ( $S S A_{\mathrm{BET}}$ ), was measured by nitrogen adsorption at $78 \mathrm{~K}$ [Autosorb $1 \mathrm{MP}$, Quantachrome] after degassing at $120^{\circ} \mathrm{C}$ for $2 \mathrm{~h}$ prior to analysis in nitrogen. Assuming uniform spherical particles within an aggregate, the average equivalent diameter of the primary particles was calculated from $d_{\mathrm{BET}}=6 / S S A_{\mathrm{BET}} \times \varrho_{\text {sample, }}$, where $S S A_{\mathrm{BET}}$ was the specific surface area $\left(\mathrm{m}^{2} / \mathrm{g}\right)$ and $\varrho_{\text {samples }}$ was the average density of $\mathrm{SnO}_{2}\left(\rho_{\mathrm{SnO}}=6.85\right.$ $\mathrm{g} / \mathrm{cm}^{3}$ [10]). The accurate morphologies of the $\mathrm{SnO}_{2}$ nanoparticles were determined by transmission electron microscopy (TEM) [JSM-2010, JEOL]. After sensing test, the cross-sectional structures of sensor were observed by scanning electron microscopy (SEM) [JSM-6335F, JEOL] analyses.

\subsection{Sensor Preparation}

An appropriate quantity of $0.28 \mathrm{~mL}$ homogeneous mixed solution was prepared by stirring and heating at $80^{\circ} \mathrm{C}$ for $12 \mathrm{~h}$ with ethyl cellulose (Fluka, $30-70 \mathrm{mPa} . \mathrm{s}$ ) as the temporary binder and terpineol (Aldrich, $90 \%$ ) as a solvent. The liquid mixture was combined with $60 \mathrm{mg}$ samples of the flame-made $\mathrm{SnO}_{2}$ nanopowders and mixed for $30 \mathrm{~min}$ to form a paste prior to spin-coating. The resulting paste was firstly spin-coated at $700 \mathrm{rpm}$ for $10 \mathrm{~s}$, and then subsequently at 3,000 rpm for $30 \mathrm{~s}$ on the $\mathrm{Al}_{2} \mathrm{O}_{3}$ substrates $(0.4 \times$ $0.5 \times 0.1 \mathrm{~cm})$ interdigitated with $\mathrm{Au}$ electrodes to deposit sensing films. The resulting substrates were annealed in an oven at $150^{\circ} \mathrm{C}$ for $1 \mathrm{~h}$ with an annealing rate of $1^{\circ} \mathrm{C} / \mathrm{min}$ and then subsequently annealed at $400^{\circ} \mathrm{C}$ for $1 \mathrm{~h}$ with an annealing rate of $1^{\circ} \mathrm{C} / \mathrm{min}$ for binder removal prior to the sensing test.

\subsection{Noxious Gases Sensing Measurements}

The gas-sensing characteristics of $\mathrm{SnO}_{2}$ sensing films were characterized over a high concentration range of $\mathrm{SO}_{2}(20-500 \mathrm{ppm})$. In contrast, it was tested specifically within a low concentration range of $\mathrm{H}_{2} \mathrm{~S}$ (0.5-10 ppm). The standard flow through technique was used to test the gas-sensing properties of $\mathrm{SnO}_{2}$ films. A constant flux of synthetic air of $21 / \mathrm{min}$ as gas carrier was flowed to mix with desired concentration of pollutants dispersed in synthetic air. All measurements were conducted in a temperaturestabilized sealed chamber at $20^{\circ} \mathrm{C}$ under controlled humidity. The gas flow rates were precisely manipulated using a computer controlled multi-channel mass flow controller. An external $\mathrm{NiCr}$ heater was heated by a regulated DC power supply to different operating temperatures ranging from $200-350^{\circ} \mathrm{C}$. The resistances of various sensors were continuously monitored with a computer-controlled system by voltage-amperometric 
technique with $10 \mathrm{~V}$ DC bias and current measurement through a picoammeter. The sensor was exposed to a gas sample for $\sim 5$ minutes for each gas concentration testing and then the air flux was restored for 15 minutes. The sensitivity $(S)$ is defined as the resistance ratio $R_{a} / R_{g}$, where $R_{a}$ is the resistance in dry air, and $R_{\mathrm{g}}$ is the resistance in the test gas. After sensors fabrication, they had been tested with varied the operating temperatures. Finally, the sensing film morphology were observed using SEM analysis.

\section{Results and Discussion}

\subsection{Particle Properties}

Figure 2 shows the XRD patterns of flame-spray-made $\mathrm{SnO}_{2}$ nanopowders. It can be seen that the nanopowders were highly crystalline and all peaks can be confirmed to be the cassiterite-tetragonal phase of $\mathrm{SnO}_{2}$ from their excellent matching to the JCPDS file NO. 77-447 [symmetrical group: $\mathrm{P}_{42} / \mathrm{mnm}$ ] with lattice constants of $\mathrm{a}=\mathrm{b}=0.4735 \mathrm{~nm}$ and $\mathrm{c}=0.3185 \mathrm{~nm}$. Figure 3 illustrates the TEM bright-field image of flamespray-made pure $\mathrm{SnO}_{2}$ nanoparticles. The corresponding electron diffraction pattern is shown in the inset. From the TEM bright-field image, $\mathrm{SnO}_{2}$ primary nanoparticles are polyhedral, non-agglomerated and well dispersed. In addition, flame-spray-made $\mathrm{SnO}_{2}$ nanoparticles indicate polyhedral aggregates of primary particles. The morphologies of flame made (5/5) $\mathrm{SnO}_{2}$ and $0.2-3 \mathrm{wt} \% \mathrm{Ru} / \mathrm{SnO}_{2}$ nanoparticles contain mainly spherical particles with diameters ranging from $3-10 \mathrm{~nm}$, and occasionally rectangular, hexagonal (3-10 nm) and rod-like ( $3-5 \mathrm{~nm}$ in width, and 5-20 nm in length) particles. From the measured SS $A_{\mathrm{BET}}$ for $\mathrm{SnO}_{2}$ nanoparticles of $141.6 \mathrm{~m}^{2} / \mathrm{g}$, the average BET-equivalent particle diameter is determined to be $6.2 \mathrm{~nm}$. The particle diameters from BET and TEM analysis are in good agreement $\left(d_{\text {BET }}=6.2 \mathrm{~nm}, d_{\text {TEM }}=3-10\right.$ $\mathrm{nm})$. The small primary-particle size and correspondingly large specific surface area of flame-spray-made $\mathrm{SnO}_{2}$ nanoparticles are highly preferred properties for gas-sensing.

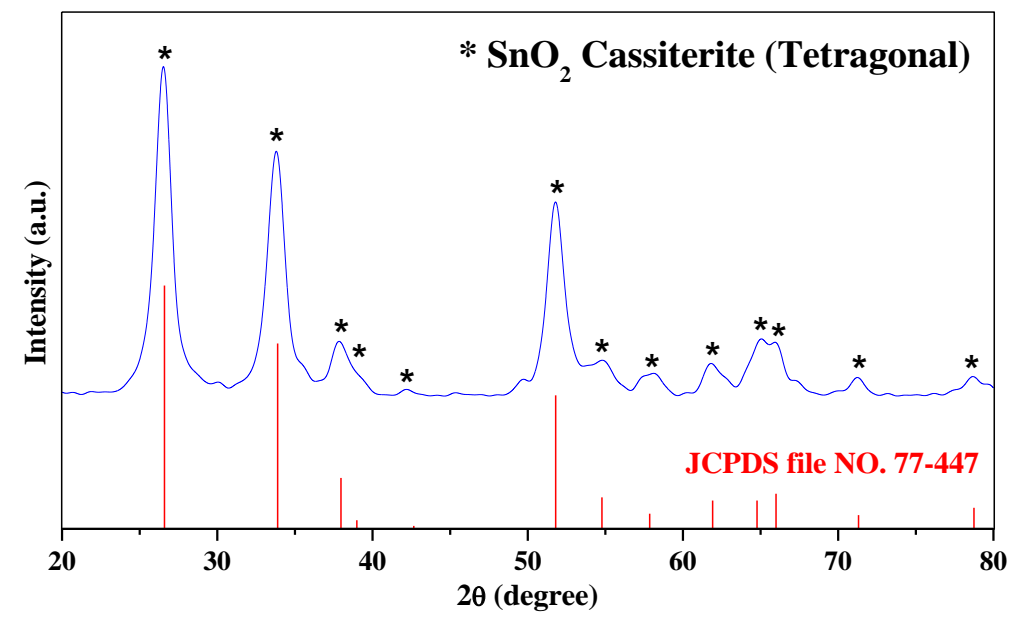

Fig. 2. XRD patterns of flame-spray-made unloaded $\mathrm{SnO}_{2}$ nanoparticles. 


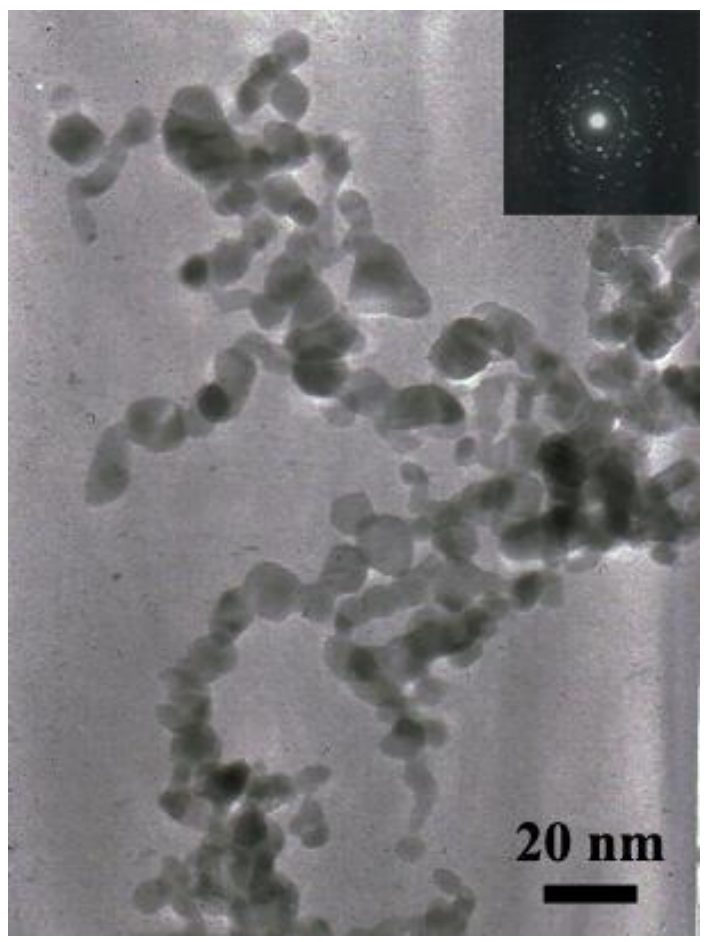

Fig. 3. TEM bright-field image of flame-spray-made unloaded $\mathrm{SnO}_{2}$ nanoparticles. Non-agglomerated particles can be observed. The corresponding electron diffraction pattern was shown in the inset.

\subsection{Noxious Gases $\left(\mathrm{SO}_{2}\right.$ and $\left.\mathrm{H}_{2} \mathrm{~S}\right)$ Sensing Properties}

Figure 4 shows the variation of the sensitivity to $\mathrm{H}_{2} \mathrm{~S}$ concentration ranging from $0.5-10 \mathrm{ppm}$ with different operating temperatures. It is observed that the sensitivity towards $\mathrm{H}_{2} \mathrm{~S}$ increases with temperature and attains a maximum value at $300^{\circ} \mathrm{C}$, followed by declining with further increase in the operating temperature. It is observed that the $\mathrm{SnO}_{2}$ sensing films responded to $10 \mathrm{ppm}$ exhibits the highest sensitivity (8.4) to $\mathrm{H}_{2} \mathrm{~S}$ at $300^{\circ} \mathrm{C}$. $\mathrm{SnO}_{2}$ is an n-type semiconductor in which the adsorbed oxygen reacts with the combustible gas releasing electrons into the conduction band by which the conductivity increases. When the sensors are exposed to air atmosphere, oxygen will be physically and chemically adsorbed on the surface of $\mathrm{SnO}_{2}$ sensing film. The adsorbed oxygen molecules act as electron acceptors and then form $\mathrm{O}^{2-}, \mathrm{O}_{2}^{-}, \mathrm{O}^{-}$, generating depleted layers resulting in the release of the large number of free electrons as followed by Eqs. (1-3). The increase of the width and height of the potential barrier at the contacts among nanocrystals and consequently lead to resistance increase of the sensors. Moreover, $\mathrm{H}_{2} \mathrm{~S}$ is also chemisorbed on the surface and the metal oxide is chemically transformed into sulfides as shown in Eq. (4).

$$
\begin{aligned}
\mathrm{H}_{2} \mathrm{~S}_{(a d s)}+3 \mathrm{O}_{(s)}^{2-} & \rightarrow \mathrm{SO}_{2(g)}+\mathrm{H}_{2} \mathrm{O}+6 e^{-} \\
2 \mathrm{H}_{2} \mathrm{~S}_{(a d s)}+3 \mathrm{O}_{2(s)}^{-} \rightarrow & 2 \mathrm{SO}_{2(g)}+2 \mathrm{H}_{2} \mathrm{O}+3 e^{-} \\
\mathrm{H}_{2} \mathrm{~S}_{(a d s)}+3 \mathrm{O}_{(s)}^{-} & \rightarrow \mathrm{SO}_{2(g)}+2 \mathrm{H}_{2} \mathrm{O}+3 e^{-} \\
2 \mathrm{H}_{2} \mathrm{~S}+\mathrm{SnO}_{2} & \leftrightarrow \mathrm{SnS}_{2}+2 \mathrm{H}_{2} \mathrm{O}
\end{aligned}
$$




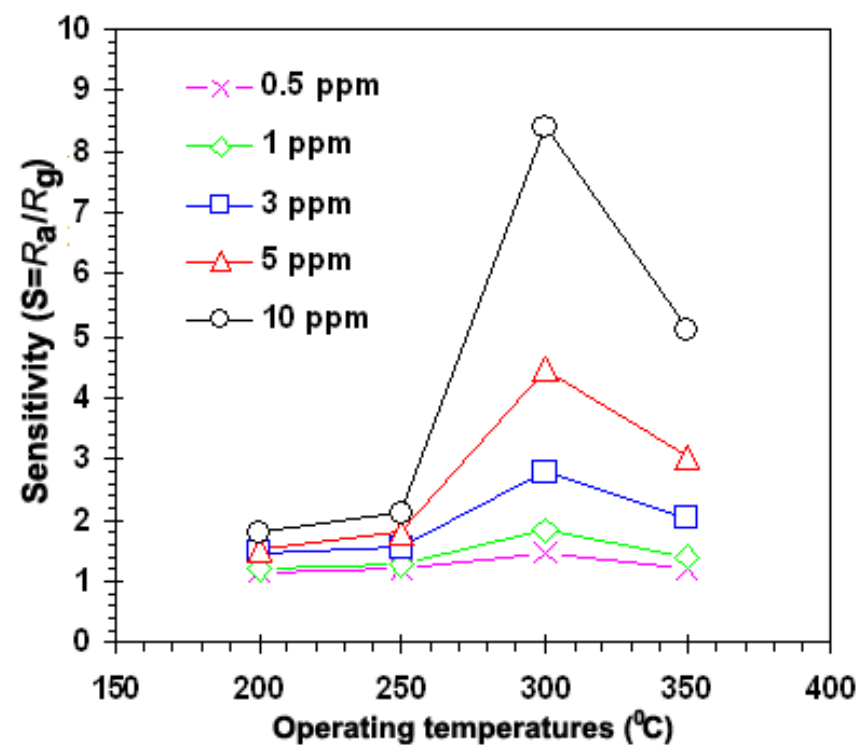

Fig. 4. Variation of the sensitivity to $0.5-10 \mathrm{ppm}$ of $\mathrm{H}_{2} \mathrm{~S}$ with different the operating temperatures ranging from $200-350^{\circ} \mathrm{C}$.

The interaction of the resistive sensors with a target gas produces a change in the electrical conductance of the sensors recorded by a variation in the electrical resistance. Figure 5 shows the change in resistance of $\mathrm{SnO}_{2}$ sensors under exposure to $\mathrm{H}_{2} \mathrm{~S}$ pulses with varying concentrations from 0.5 to $10 \mathrm{ppm}$ at operating temperatures ranging from $200-350^{\circ} \mathrm{C}$ during backward cycle. The resistance reduction is clearly seen at all gas concentrations indicating that the $\mathrm{SnO}_{2}$ sensor has typical n-type semiconductor behaviors. It can be noticed that the operating temperature at $300^{\circ} \mathrm{C}$ shows the best response with evident decreasing the resistance than the other operating temperatures. Thus, this suitable operating temperature can greatly improve $\mathrm{H}_{2} \mathrm{~S}$ response of $\mathrm{SnO}_{2}$ sensors. In addition, $\mathrm{SnO}_{2}$ sensor had fast response with rather stable in recovery baseline even at low operating temperature of $300^{\circ} \mathrm{C}$.

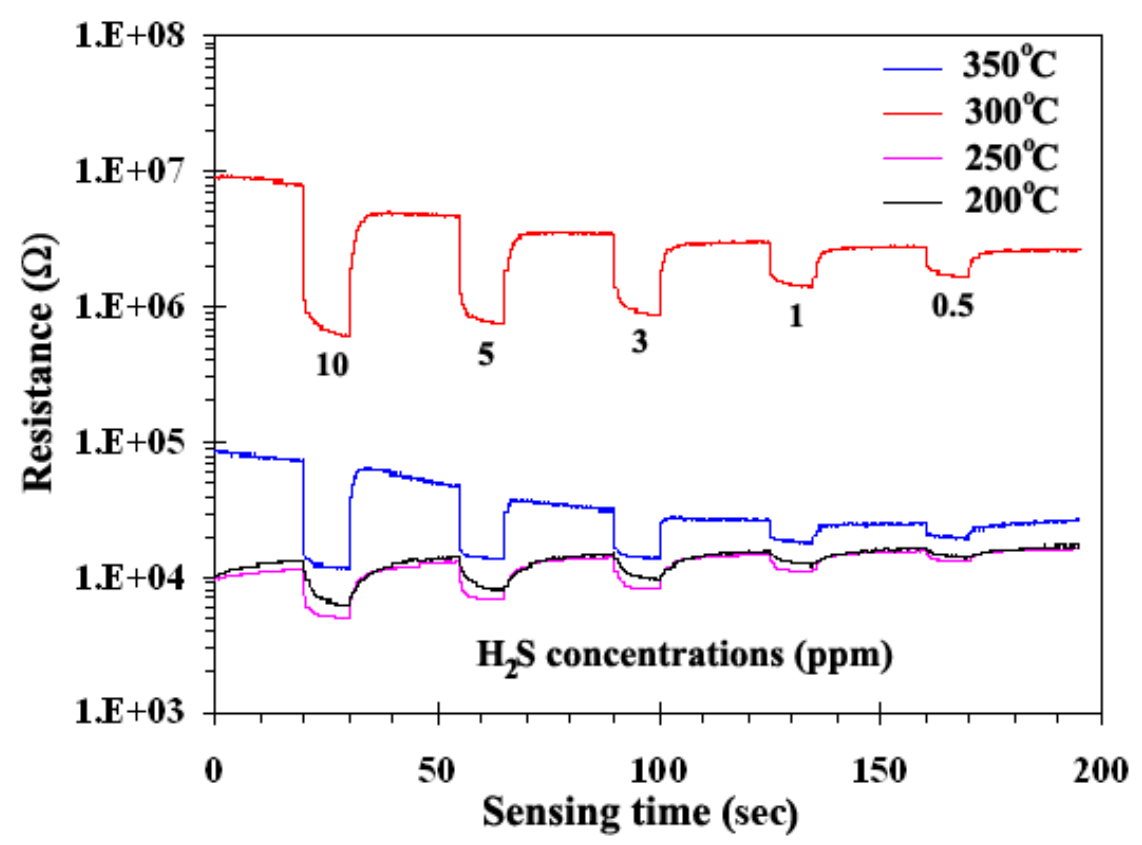

Fig. 5. Change in resistance of $\mathrm{SnO}_{2}$ sensor upon exposure to $\mathrm{H}_{2} \mathrm{~S}$ at operating temperatures ranging from $200-350^{\circ} \mathrm{C}$. 
Figures 6(a) and 6(b) show the plot of response $(S)$ and response times $\left(T_{\text {res }}\right)$ for the $\mathrm{SnO}_{2}$ sensor versus concentrations of noxious $\mathrm{H}_{2} \mathrm{~S}\left(0.5-10 \mathrm{ppm}\right.$, Fig. 6(a)) and $\mathrm{SO}_{2}(20-500 \mathrm{ppm}$, Fig. 6(b)) gases at operating temperatures ranging from $200-350^{\circ} \mathrm{C}$. In Fig. 6 (a), it was clear that the responses (left) increased and the response times (right) drastically decreased with increasing $\mathrm{H}_{2} \mathrm{~S}$ concentrations. For both $\mathrm{H}_{2} \mathrm{~S}$ and $\mathrm{SO}_{2}$ (Figs. 6 (a) and 6 (b)), it can be seen that sensor had the best sensing performances at $300^{\circ} \mathrm{C}$ than the other operating temperatures with the highest response and the shortest response times. The better $\mathrm{H}_{2} \mathrm{~S}$ sensing performance in terms of the response $(S=8.4)$ and response time $(3 \mathrm{~s})$ are obtained at the highest concentration $(10 \mathrm{ppm})$ at $300^{\circ} \mathrm{C}$, while the response $(S=6.9)$ and response time (12 s) to higher concentration of 500 ppm were considerably lower (Fig. 6 (b)) through performed higher concentration. The $\mathrm{SnO}_{2}$ sensor shows very fast response to $\mathrm{H}_{2} \mathrm{~S}$ whereas the responses to $\mathrm{SO}_{2}$ are somewhat sluggish. While the sensor reveals quite low $\mathrm{SO}_{2}$ response at $500 \mathrm{ppm}, \mathrm{H}_{2} \mathrm{~S}$ sensing yields much higher response at lower concentration, enabling more accurate detection of the small leakage in an atmosphere form the industrial environment. The superior sensitivity toward $\mathrm{H}_{2} \mathrm{Smay}$ be explained from the reaction kinetic of $\mathrm{H}_{2} \mathrm{~S}$ and $\mathrm{SO}_{2}$ according to the reaction paths (1) and (5):

$$
\mathrm{SO}_{2(a d s)}+\mathrm{O}_{(s)}^{2-} \rightarrow \mathrm{SO}_{3(g)}+2 e^{-}
$$

It can be seen that $\mathrm{H}_{2} \mathrm{~S}$ molecule can produce three times of the number of free electrons per reaction compared to that of $\mathrm{SO}_{2}$ one therefore the sensitivity of the sensor to $\mathrm{H}_{2} \mathrm{~S}$ is significantly higher. It should also be noted that $\mathrm{SO}_{2}$ was characterized only in the range of $20-500 \mathrm{ppm}$ because of the limitation of the present gas mixing system, in which the dilution is limited to $2 \%$ of the $\mathrm{SO}_{2}$ gas source concentration of 2,000 ppm. However, it can be predicted from the gas sensitivity curve (Fig. 6 (b)) that the sensor does not possess appreciable sensitivity toward the exposure limit of $2-5 \mathrm{ppm}$. Thus, the sensor is not particularly suitable for $\mathrm{SO}_{2}$ detection in atmosphere.
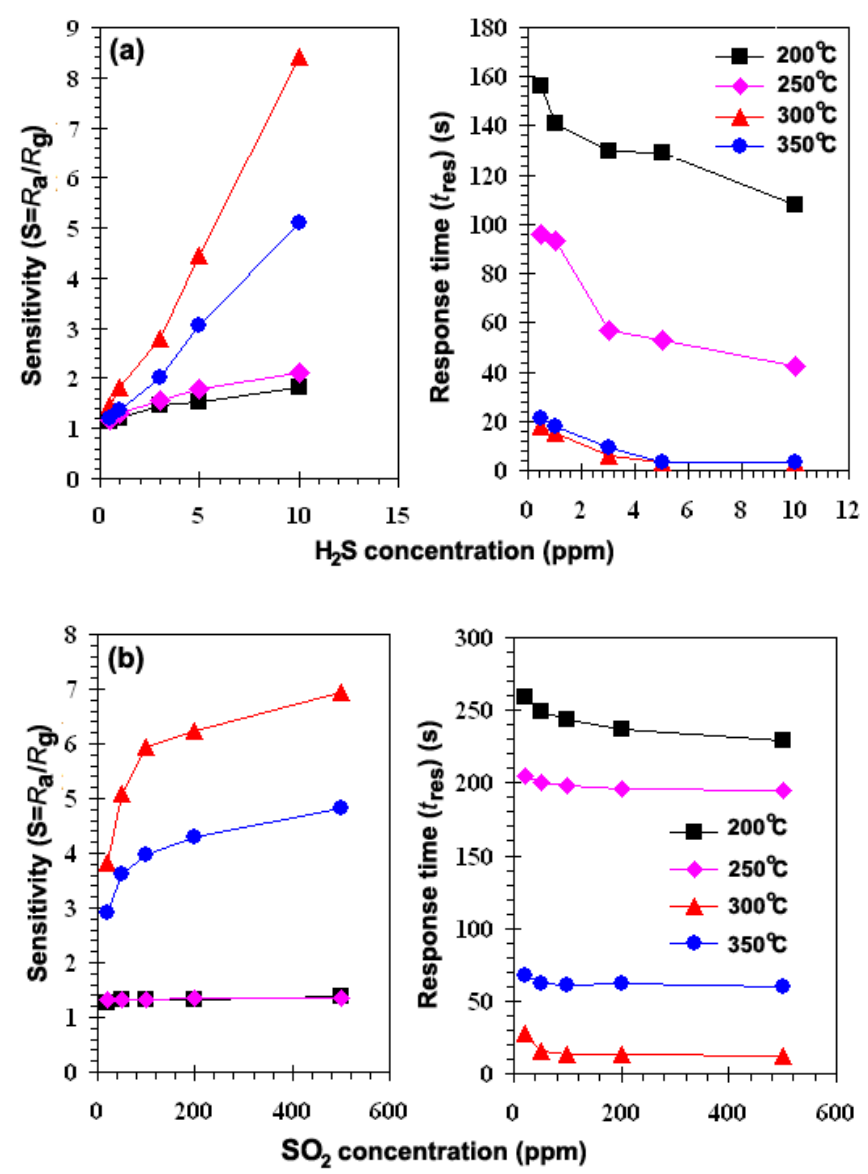

Fig. 6. Sensitivity (left) and corresponding response time (right) of $\mathrm{SnO}_{2}$ sensors as a function of (a) $\mathrm{H}_{2} \mathrm{~S}$ and (b) $\mathrm{SO}_{2}$ concentrations in dry air at the operating ranging from $200-350^{\circ} \mathrm{C}$. 
The recovery times for these gases (not shown) were within a few minutes. This is due possibly to slow desorption of gas species from highly porous $\mathrm{SnO}_{2}$ nanostructures. This is consistent with Griessler et. al [5] mentioned the nanosensors based on ultrathin $\mathrm{SnO}_{2}$ films, which were very sensitive to the highly toxic gases $\mathrm{SO}_{2}$ and $\mathrm{H}_{2} \mathrm{~S}$. The $\mathrm{SnO}_{2}$-sensing films are fabricated by a spray pyrolysis process on $\mathrm{Si}$ substrates with a thickness of $50 \mathrm{~nm}$. The sensor resistance was decreased in the presence of the toxic gases. Exposure to $50 \mathrm{ppm} \mathrm{SO} \mathrm{S}_{2}$ leads to a sensor resistance drop of $\sim 40 \%$ whereas a $\mathrm{H}_{2} \mathrm{~S}$ gas concentration of only $2.5 \mathrm{ppm}$ decreases the resistance by $\sim 85 \%$, which demonstrates the extraordinary sensitivity of the nanosensors. Furthermore, Ghimbeu et al. [7] reported the ability of electrostatic sprayed $\mathrm{SnO}_{2}$ and $\mathrm{CuO} / \mathrm{SnO}_{2}(1,2$, and 4 at.\% $\mathrm{Cu}$ ) films to detect different pollutant gases, i.e., $\mathrm{H}_{2} \mathrm{~S}, \mathrm{SO}_{2}$, and $\mathrm{NO}_{2}$. The $\mathrm{SnO}_{2}$ films had low response of $\mathrm{H}_{2} \mathrm{~S}(\sim 6$ to $10 \mathrm{ppm})$ and $\mathrm{SO}_{2}(\sim 1$ to $20 \mathrm{ppm})$ at low operating temperature of $100^{\circ} \mathrm{C}$. Among the studied films, the 1 at. $\% \mathrm{Cu}$-doped $\mathrm{SnO}_{2}$ layer is the most sensitive in the detection of all the studied gases. Therefore, the $\mathrm{SnO}_{2}$ sensor has been one of the most suitable candidates for the efficient detection of noxious gases for industrial environment especially $\mathrm{H}_{2} \mathrm{~S}$ at very low detections limits. The detection limit can be estimated from the characteristic curve using the standard power law for gas sensor. Taking the threshold response for detection limit of 1.05 (resistance change of 5\%), the detection limits for $\mathrm{H}_{2} \mathrm{~S}$ are $0.33,0.32,0.35$ and $0.49 \mathrm{ppm}$ at $200,250,300$ and $350^{\circ} \mathrm{C}$, respectively. Similarly the detection limits for $\mathrm{SO}_{2}$ are 5.1, 3.2, 1.0 and $1.9 \mathrm{ppm}$ at $200,250,300$ and $350^{\circ} \mathrm{C}$, respectively. Thus, the sensor has optimal detection limits at $300^{\circ} \mathrm{C}$ operating temperature for both gases.

A summary of gas-sensing performance of pure $\mathrm{SnO}_{2}$ prepared by various synthetic methods was shown in Table 1. It can be seen that spin-coated FSP-prepared $\mathrm{SnO}_{2}$ film in the present work exhibits much better $\mathrm{H}_{2} \mathrm{~S}$ selectivity than other reported $\mathrm{H}_{2} \mathrm{~S}$ sensors. The sensor characteristics including response and response/recovery time of sensing films can considerably be affected by the particle morphology, size and distribution as well as operating temperature. The main advantage of FSP includes ability to produce well-controlled nanosized particles with high crystallinity structure suitable for gas sensing. However, the differences between our result and those of other flame-spray-made $\mathrm{SnO}_{2}$ films suggest that the method for deposition of FSP nanoparticles on substrate is also very important. Spin coating technique used in this work which can produce uniform porous film with high particle density, resulting in relatively larger specific surface area and higher gas adsorption.

\subsection{Environmental Selectivity}

Resistive gas sensors with metal oxide layers are frequently used for monitoring environmental gases particularly toxic gases in air due to their high response and good long term stability. The cross sensitivities of the sensor towards different concentrations of $\mathrm{H}_{2} \mathrm{~S}, \mathrm{CO}, \mathrm{H}_{2}$, and $\mathrm{C}_{2} \mathrm{H}_{2}$ were measured at $300^{\circ} \mathrm{C}$ (Fig. 7). The sensor evidently shows much less response to $\mathrm{CO}, \mathrm{H}_{2}$, and $\mathrm{C}_{2} \mathrm{H}_{2}$ than to $\mathrm{H}_{2} \mathrm{~S}$ indicating high selectivity for $\mathrm{H}_{2} \mathrm{~S}$ of the $\mathrm{SnO}_{2}$ sensor at the lower concentration $(10 \mathrm{ppm})$. The selectivity experiment for $\mathrm{SnO}_{2}$ sensing film was carried out by monitoring changes in resistance upon exposure to several gases in both high $(200 \mathrm{ppm}, 500 \mathrm{ppm})$ and low concentration $(10 \mathrm{ppm})$ ranges. The several environmental gases were also comparatively tested at the concentrations of $200 \mathrm{ppm}$ for $\mathrm{CO}$, and $\mathrm{H}_{2} \mathrm{~S}, 500 \mathrm{ppm}$ for $\mathrm{H}_{2}$ and $10 \mathrm{ppm}$ for $\mathrm{H}_{2} \mathrm{~S}$ at the operating temperature of $300^{\circ} \mathrm{C}$. The other environmental gases $\left(\mathrm{CO}, \mathrm{H}_{2}\right.$, and $\left.\mathrm{C}_{2} \mathrm{H}_{2}\right)$ were tested at relatively high concentrations because their responses were negligible at the low concentration of $10 \mathrm{ppm}$. It can be clearly seen that the $\mathrm{SnO}_{2}$ sensor is evidently higher selective towards $\mathrm{H}_{2} \mathrm{~S}$ through the lower concentration as it exhibits much higher resistance increase after interaction with $\mathrm{H}_{2} \mathrm{~S}$ gas molecules at the operating temperature of $300^{\circ} \mathrm{C}$. On the other hand, there are much small decreases in the sensor resistance upon exposure to other interfering gases including $\mathrm{CO}, \mathrm{H}_{2}$ and $\mathrm{C}_{2} \mathrm{H}_{2}$. 
Table 1. Summary of gas-sensing performances of pure $\mathrm{SnO}_{2}$ materials prepared by various synthetic methods

\begin{tabular}{|c|c|c|c|c|c|c|}
\hline \multirow{2}{*}{ Authors } & \multirow{2}{*}{ Methods } & \multirow{2}{*}{ Materials } & \multirow{2}{*}{ Gas Conc. } & \multicolumn{3}{|c|}{ Sensing performances } \\
\hline & & & & Response $(\mathcal{S})$ & $t_{\mathrm{res}}$ & Selectivity \\
\hline $\begin{array}{l}\text { Sahm et } \\
\text { al. [10] }\end{array}$ & $\begin{array}{l}\text { FSP } \\
\text { (nanopowders) } \\
\text { Drop coating } \\
\text { (sensors) }\end{array}$ & Pure $\mathrm{SnO}_{2}$ & $\begin{array}{l}\mathrm{NO}_{2} \\
(10-5,000 \mathrm{ppb}) \\
\mathrm{CO}(500-10,000 \\
\text { ppm), propanol } \\
(10-300 \mathrm{ppm})\end{array}$ & $\begin{array}{l}\mathrm{NO}_{2} ; \sim 20 \text { to } 5,000 \mathrm{ppb} \\
\text { at } 220^{\circ} \mathrm{C} \\
\text { Propanal; } 300 \text { to } 150 \\
\text { ppm at } 220^{\circ} \mathrm{C}\end{array}$ & - & $\begin{array}{l}\mathrm{NO}_{2} ; S \sim 20 \text { to } \\
5,000 \mathrm{ppb}\end{array}$ \\
\hline $\begin{array}{l}\text { Mädler et } \\
\text { al. [11] }\end{array}$ & $\begin{array}{l}\text { FSP } \\
\text { (nanopowders) } \\
\text { Thermophoretic } \\
\text { deposition } \\
\text { (sensors) }\end{array}$ & $\begin{array}{l}0.2 \\
\mathrm{wt} / \mathrm{Pt} / \mathrm{SnO}_{2}\end{array}$ & $\mathrm{CO} ; 50 \mathrm{ppm}$ & 8 to $50 \mathrm{ppm}$ at $350^{\circ} \mathrm{C}$ & - & - \\
\hline $\begin{array}{l}\text { Jin et al. } \\
{[3] \text {. }}\end{array}$ & $\begin{array}{l}\text { DC magnetron } \\
\text { sputtering } \\
\text { (sensors) }\end{array}$ & $\begin{array}{l}\text { Pure } \mathrm{SnO}_{2} \\
\text { films, } \mathrm{Ag}_{-}, \mathrm{Cu}-\text {, } \\
\text { Pt-, Pd-doped } \\
\mathrm{SnO}_{2} \text { films } \\
(1-16 \mathrm{~nm})\end{array}$ & $\mathrm{H}_{2} \mathrm{~S} ; 1 \mathrm{ppm}$ & $\begin{array}{l}\text { Doping film }=16 \mathrm{~nm} \\
\text { Response to } \mathrm{H}_{2} \mathrm{~S} \\
\text { at } 200^{\circ} \mathrm{C}, 5900 ; 1 \mathrm{ppm} \\
\text { at } 250^{\circ} \mathrm{C}, 590 ; 1 \mathrm{ppm}\end{array}$ & second & - \\
\hline $\begin{array}{l}\text { Gong et } \\
\text { al. [4] }\end{array}$ & Sol-gel & $\begin{array}{l}\text { Pure } \mathrm{SnO}_{2} \text { and } \\
\mathrm{Ag} / \mathrm{SnO}_{2}\end{array}$ & $\mathrm{H}_{2} \mathrm{~S} ; 1-25 \mathrm{ppm}$ & $\begin{array}{l}>120 \text { to } 10 \mathrm{ppm}, 70^{\circ} \mathrm{C}, \\
9 \% \text { R.h. } \\
\sim 90 \text { to } 5 \mathrm{ppm}, 70^{\circ} \mathrm{C}, \\
9 \% \text { R.h. } \\
\sim 55 \text { to } 2 \mathrm{ppm}, 70^{\circ} \mathrm{C}, \\
9 \% \text { R.h. }\end{array}$ & - & $\begin{array}{l}\mathrm{H}_{2} \mathrm{~S}, S>120 \text { to } 10 \\
\text { ppm, } 70^{\circ} \mathrm{C} \\
\text { Other gases; } \\
S<3 \\
\mathrm{Cl}_{2}(10 \mathrm{ppm}), \mathrm{HCl} \\
(10 \mathrm{ppm}), \mathrm{HCN}(10 \\
\mathrm{ppm}^{\circ}, \mathrm{SO}_{2}(9 \mathrm{ppm}), \\
\mathrm{C}_{6} \mathrm{H}_{14}(0.3 \%), \mathrm{CH}_{4} \\
(2.2 \%), \mathrm{CO}(50 \\
\mathrm{ppm}), \mathrm{C}_{3} \mathrm{H}_{8} \\
(0.44 \%), \mathrm{NO}_{2} \\
(5 \mathrm{ppm})\end{array}$ \\
\hline $\begin{array}{l}\text { Griessler } \\
\text { et al. [5] }\end{array}$ & $\begin{array}{l}\text { Spray pyrolysis } \\
\text { process }\end{array}$ & $\begin{array}{l}\text { Pure } \mathrm{SnO}_{2} \text { thin } \\
\text { film }(50 \mathrm{ppm})\end{array}$ & $\begin{array}{l}\mathrm{H}_{2} \mathrm{~S}(2.5 \mathrm{ppm}) \\
\text { and } \mathrm{SO}_{2}(50 \\
\text { ppm })\end{array}$ & $\begin{array}{l}\mathrm{H}_{2} \mathrm{~S}(2.5 \mathrm{ppm}), 400^{\circ} \mathrm{C}, \\
\sim 85 \% \\
\mathrm{SO}_{2}(50 \mathrm{ppm}), 300^{\circ} \mathrm{C}, \sim \\
40 \%\end{array}$ & - & - \\
\hline $\begin{array}{l}\text { Das et al. } \\
\text { [9] }\end{array}$ & $\begin{array}{l}\text { Simultaneous } \\
\text { precipitation } \\
\text { technique } \\
\text { (nanopowders) } \\
\text { Screen printing } \\
\text { (sensor) }\end{array}$ & $\begin{array}{l}\text { Pure } \mathrm{SnO}_{2} \\
(40-50 \mathrm{~nm}) \\
\text { and } 0.1-1 \\
\mathrm{wt}^{0} / \mathrm{V}_{2} \mathrm{O}_{5} / \mathrm{Sn} \\
\mathrm{O}_{2}(14-17 \mathrm{~nm})\end{array}$ & $\begin{array}{l}\mathrm{SO}_{2}(5,100 \\
\mathrm{ppm})\end{array}$ & $\begin{array}{l}\text { Response of } \mathrm{SO}_{2}(5 \\
\text { ppm) at } 350^{\circ} \mathrm{C} \text { of } \mathrm{SnO}_{2} \\
(\sim 20 \%) \text { and } 0.15 \\
\mathrm{wt}^{\circ} \% \mathrm{~V}_{2} \mathrm{O}_{5} / \mathrm{SnO}_{2}(\sim \\
45 \%) \\
\text { Response to } 100 \mathrm{ppm} \\
\text { at } 350^{\circ} \mathrm{C} \text { of } \mathrm{SnO}_{2}(\sim \\
35 \%) \text { and } 0.15 \\
\mathrm{wt}^{\circ} \% \mathrm{~V}_{2} \mathrm{O}_{5} / \mathrm{SnO}_{2}(\sim \\
70 \%)\end{array}$ & - & $\begin{array}{l}S<30 \% \\
\mathrm{CH}_{4}(100 \mathrm{ppm}), \\
\mathrm{CH}_{4} \mathrm{H}_{10}(100 \mathrm{ppm}), \\
\mathrm{CO}(100 \mathrm{ppm})\end{array}$ \\
\hline $\begin{array}{l}\text { Present } \\
\text { work }\end{array}$ & $\begin{array}{l}\text { FSP } \\
\text { (nanopowders) } \\
\text { Spin coating } \\
\text { (sensors) }\end{array}$ & Pure $\mathrm{SnO}_{2}$ & $\begin{array}{l}\mathrm{SO}_{2} ; 20-500 \\
\mathrm{ppm} \\
\mathrm{H}_{2} \mathrm{~S} ; 0.5-10 \\
\text { ppm }\end{array}$ & $\begin{array}{l}\text { Response to } 20-50 \\
\mathrm{ppm} \text { of } \mathrm{SO}_{2} \\
\sim 3.8-6.8,300^{\circ} \mathrm{C} \\
\text { Response to } 0.5-10 \\
\mathrm{ppm} \text { of } \mathrm{H}_{2} \mathrm{~S} \\
\sim 1.4-8.4,300^{\circ} \mathrm{C}\end{array}$ & $\begin{array}{l}500 \mathrm{ppm} \\
\text { of } \mathrm{SO}_{2} \\
10 \mathrm{~s} \\
300^{\circ} \mathrm{C} \\
10 \mathrm{ppm} \\
\text { of } \mathrm{H}_{2} \mathrm{~S} \\
3 \mathrm{~s}, \\
300^{\circ} \mathrm{C}\end{array}$ & $\begin{array}{l}\text { Other gases like } \\
\mathrm{CO}(200 \mathrm{ppm}) ; \\
\mathrm{C}_{2} \mathrm{H}_{2}(200 \mathrm{ppm}) \\
\mathrm{H}_{2}(500 \mathrm{ppm}) \\
S<2\end{array}$ \\
\hline
\end{tabular}




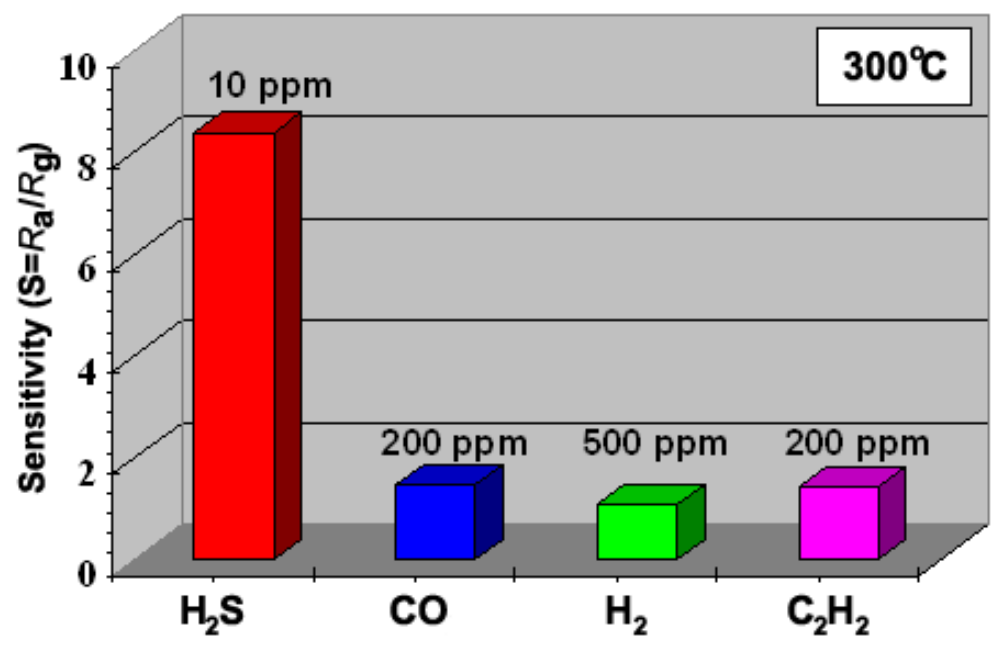

Fig. 7. The selectivity histogram of $\mathrm{SnO}_{2}$ sensor for environmental monitoring including the $\mathrm{H}_{2} \mathrm{~S}, \mathrm{CO}, \mathrm{H}_{2}$ and $\mathrm{C}_{2} \mathrm{H}_{2}$ at low concentration of $10 \mathrm{ppm}$ for $\mathrm{H}_{2} \mathrm{~S}$ and high concentrations of $200 \mathrm{ppm}$ and 500 ppm for $\mathrm{CO}, \mathrm{C}_{2} \mathrm{H}_{2}$ and $\mathrm{H}_{2}$, respectively, at the operating temperatures of $300^{\circ} \mathrm{C}$.

\subsection{Sensing Film Morphology}

The cross-section, film thickness, and surface morphology of the $\mathrm{SnO}_{2}$ sensing layer after annealing and sensing ranging from $200-350^{\circ} \mathrm{C}$ were observed using SEM analysis as shown in Fig. 8. It can be seen that the film thickness of sensing film is approximately $5 \mu \mathrm{m}$ (side view), which benefits tremendously to gassensing properties. The $\mathrm{SnO}_{2}$ sensing layer is crack-free and contains very high density nanoparticles. It was formed after annealing in air for binder removal at $400^{\circ} \mathrm{C}$ for $1 \mathrm{~h}$ and repeated gas-sensing measurement ranging from $200-350^{\circ} \mathrm{C}$. After annealing and sensing processes, a denser film layer was formed. The regularity in the film thickness stems from the uniformity of binder-powder mixing and spin coating process.

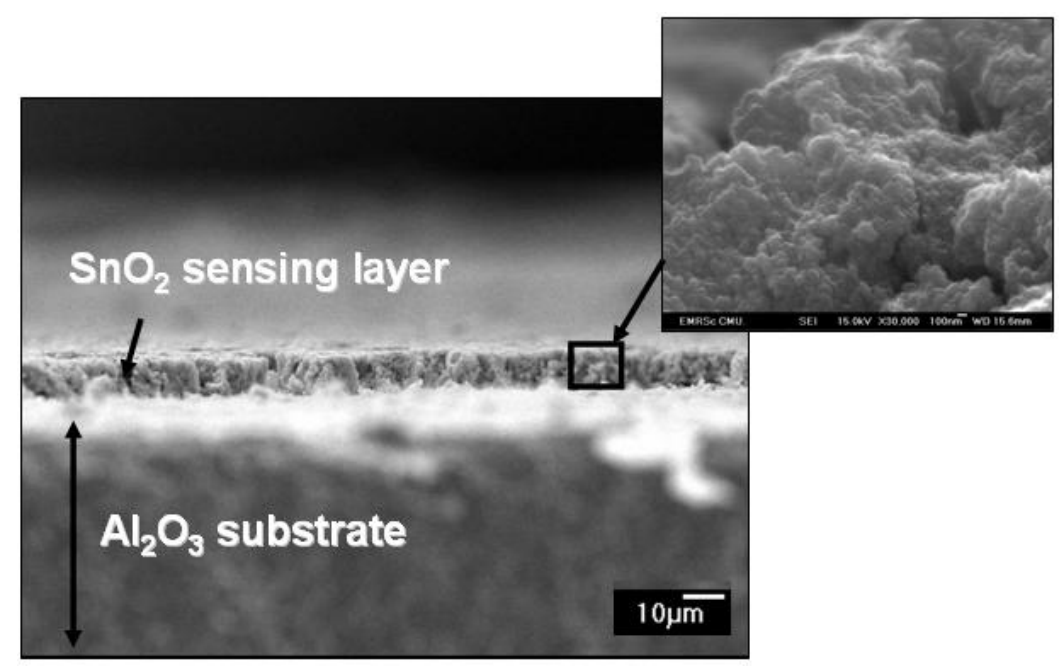

Fig. 8. SEM micrographs of $\mathrm{SnO}_{2}$ sensing film spin-coated on an $\mathrm{Al}_{2} \mathrm{O}_{3}$ substrate with interdigitated $\mathrm{Au}$ electrodes after annealing at $400^{\circ} \mathrm{C}$ and gas-sensing measurement ranging from $200-350^{\circ} \mathrm{C}$ in dry air. The film thickness was approximately $5 \mu \mathrm{m}$.

\section{Conclusions}

In conclusion, the monitoring of suitable sensitive sensors for noxious gas in an industrials environment was fabricated by spin coating of flame-spray-made $\mathrm{SnO}_{2}$ nanoparticles. The sizes and dimensional 
structures (outer diameter of nanoparticles and 2D film thickness) played an important role in increasing the specific surface area of sensing layer. The nanoparticles were found to have a high specific surface area $\left(S S A_{\text {BET: }}: 141.6 \mathrm{~m}^{2} / \mathrm{g}\right)$, which could significantly enhance surface ionization reaction from adsorption and desorption of oxygen and gas species. The continuous sensing film was achieved leading to the connectivity of nanoparticles' properties. The $\mathrm{SnO}_{2}$ sensor was tested to $\mathrm{H}_{2} \mathrm{~S}$ and $\mathrm{SO}_{2}$ with different concentration ranges. The $\mathrm{SnO}_{2}$ sensor exhibited much higher response and selectivity to $\mathrm{H}_{2} \mathrm{~S}$ (to $10 \mathrm{ppm}, S=8.4$ ) against other gases at high concentration and operating temperature of $300^{\circ} \mathrm{C}$. The response time was very fast $(3 \mathrm{~s})$ to $10 \mathrm{ppm}$ of $\mathrm{H}_{2} \mathrm{~S}$ gas. Therefore, the $\mathrm{SnO}_{2}$ sensor was one of the most suitable candidates for the efficient detection of noxious $\mathrm{H}_{2} \mathrm{~S}$ gas at low ppm-level for leakage prevention from industrials environment.

\section{Acknowledgements}

The authors gratefully acknowledge the financial support from the Thailand Research Fund (TRF); the National Research University Project under the Office of the Higher Education Commission, Ministry of Education, the National Nanotechnology Center (NANOTEC), NSTDA, Ministry of Science and Technology, through its program of Center of Excellence Network, Thailand, the Materials Science Research Center, Department of Physics and Materials Science, Faculty of Science, Chiang Mai University, Thailand and National Electronics and Computer Technology Center (NECTEC), Pathumthani, Thailand.

\section{References}

[1] C. H. Liu, L. Zhang, and Y.-J. He, "Properties and mechanism study of Ag doped $\mathrm{SnO}_{2}$ thin films as $\mathrm{H}_{2} \mathrm{~S}$ sensors," Thin Solid Films, vol. 304, pp. 13-15, Feb. 1997.

[2] R. S. Niranjan, K. R. Patil, S. R. Sainkar, and I. S. Mulla, "High $\mathrm{H}_{2} \mathrm{~S}$-sensitive copper-doped tin oxide thin film," Mater. Chem. Phys., vol. 80, pp. 250-256, Oct. 2003.

[3] C. Jin, T. Yamazaki, K. Ito, T. Kikuta, and N. Nakatani, " $\mathrm{H}_{2} \mathrm{~S}$ sensing property of porous $\mathrm{SnO}_{2}$ sputtered films coated with various doping films," Vacuum, vol. 80, pp. 723-725, 2006.

[4] J. Gong, Q. Chen, M-R. Lian, N-C. Liu, R. G. Stevenson, and F. Adami, "Micromachined nanocrystalline silver doped $\mathrm{SnO}_{2} \mathrm{H}_{2} \mathrm{~S}$ sensor," Sens. Actuators B: Chem., vol. 114, pp. 32-39, June 2006.

[5] C. Griessler, E. Brunet, T. Maier, S. Steinhauer, A. Köck, T. Jordi, F. Schrank, and M. Schrems, "Tin oxide nanosensors for highly sensitive toxic gas detection and their 3D system integration," Microelec. Eng., vol. 88, pp. 1779-1781, Feb., 2011.

[6] C. M. Ghimbeu, M. Lumbreras, J. Schoonman, and M. Siadat, "Electrosprayed metal oxide semiconductor films for sensitive and selective detection of hydrogen sulfide," Sensors, vol. 9, pp. 9122-9132, Nov., 2009.

[7] C. M. Ghimbeu, M. Lumbreras, M. Siadat, R. C. van Landschoot, and J. Schoonman, "Electrostatic sprayed $\mathrm{SnO}_{2}$ and $\mathrm{Cu}$-doped $\mathrm{SnO}_{2}$ films for $\mathrm{H}_{2} \mathrm{~S}$ detection," Sens. Actuators B: Chem., vol. 133, pp. 694-698, Apr. 2008.

[8] J. Kaur, S. C. Roy, and M. C. Bhatnagar, "Highly sensitive $\mathrm{SnO}_{2}$ thin film $\mathrm{NO}_{2}$ gas sensor operating at low temperature," Sens. Actuators B: Chem., vol. 123, pp. 1090-1095, 2007.

[9] S. Das, S. Chakraborty, O. Parkash, D. Kumar, S. Bandyopadhyay, S. K. Samudrala, A. Sen, and H. S. Maiti, "Vanadium doped tin dioxide as a novel sulfur dioxide sensor," Talanta, vol. 75, pp. 385-389, Nov. 2008.

[10] T Sahm, L. Mädler, A. Gurlo, N. Barsan, S. E. Pratsinis, and U. Weimar "Flame spray synthesis of tin dioxide nanoparticles for gas sensing," Sens. Actuators B: Chem., vol. 98, pp. 148-153, 2004.

[11] L. Mädler, A. Roessler, S. E. Pratsinis, T. Sahm, A. Gurlo, N. Barsan, and U. Weimar, "Direct formation of highly porous gas-sensing films by in situ thermophoretic deposition of flame-made Pt/SnO 2 nanoparticles," Sens. Actuators B: Chem., vol. 114, pp. 283-295, 2005.

[12] L. Mädler, T. Sahm, A. Gurlo, J.-D. Grunwaldt, N. Barsan, U. Weimar, and S. E. Pratsinis, "Sensing low concentrations of $\mathrm{CO}$ using flame-spray-made $\mathrm{Pt} / \mathrm{SnO}_{2}$ nanoparticles," J. Nanopart. Res., vol. 8, pp. 783-796, 2006.

[13] C. Liewhiran and S. Phanichphant, "Influence of thickness on ethanol sensing characteristics of doctor-bladed thick film from flame-made ZnO nanoparticles," Sensors, vol. 7, pp. 185-201, 2007.

[14] C Liewhiran and S. Phanichphant, "Improvement of flame-made nanoparticulate thick film morphology for ethanol sensing," Sensors, vol. 7, pp. 650-675, 2007. 
[15] C. Liewhiran and S. Phanichphant, "Effects of palladium loading on the response of a thick film flame-made Zno gas sensor for detection of ethanol vapor," Sensors, vol. 7, pp. 1159-1184, 2007.

[16] C. Liewhiran and S. Phanichphant "Doctor-bladed thick films of flame-made Pd/ZnO nanoparticles for ethanol sensing," Curr. Appl. Phys., vol. 8, pp. 336-339, 2008.

[17] C. Liewhiran, N. Tamaekong, A. Wisitsoraat, and S. Phanichphant, " $\mathrm{H}_{2}$ sensing response of flamespray-made $\mathrm{Ru} / \mathrm{SnO}_{2}$ thick films fabricated from spin-coated nanoparticles," Sensors, vol. 9, pp.89969010, 2009.

[18] S. E. Pratsinis, "Flame aerosol synthesis of ceramic powders," Prog. Energ. Combust., vol. 24 pp. $197-$ 219, 1998.

[19] L. Mädler, H. K. Kammler, R. Mueller, and S. E. Pratsinis, "Controlled synthesis of nanostructured particles by flame spray pyrolysis," J. Aeros. Sci., vol. 33, pp. 369-389, 2002.

[20] R. Mueller, L. Mädler, and S. E. Pratsinis, "Nanoparticle synthesis at high production rates by flame spray pyrolysis," Chem. Eng. Sci., vol. 58, pp. 1969-1976, 2003. 